\title{
PSYCHOLOGY OF PATIENCE IN AL-MISBĀH EXEGESIS
}

\author{
Muh. Tajab ${ }^{*}$, Abd. Madjid ${ }^{2}$, Mega Hidayati ${ }^{3}$ \\ ${ }^{1}$ Graduate Student, Universitas Muhammadiyah Yogyakarta, Indonesia, ${ }^{2}$ Doctor of Islamic Education Psychology, \\ Universitas Muhammadiyah Yogyakarta, Indonesia, ${ }^{3}$ Doctor of Islamic Politics/Political Sciences, Universitas \\ Muhammadiyah Yogyakarta, Indonesia. \\ Email: ${ }^{1 *}$ Mtajab@gmail.com, ${ }^{2}$ abdulmadjid@umy.ic.id, ${ }^{3}$ mega.hidayati@umy.ic.id
}

Article History: Received on $17^{\text {th }}$ August 2019, Revised on $30^{\text {th }}$ September 2019, Published on $07^{\text {th }}$ November 2019

\begin{abstract}
Purpose of the study: The aim of the research is to analyze Patience in the al-Misbāh Exegesis work of M. Quraish Shihab from Indonesia, especially to describe and analyze the relationship of patience with the personality in tafsīr alMisbāh.

Methodology: This research is library research using text study methods. In the study of interpretive texts, one of them is the method of interpretation of mauḍu'i. The method of tafsīrmauḍu'i is a method of interpretation that discusses a particular theme, then seeks the view of the al-Qur'an on the matter by grouping verses, analyzing, discussing and understanding verse by verse, then gathering general verses into specific verses. In analyzing, text studies utilize library sources as a study material. The method used tafsirthematic, which means to collect verses of the Qur'an correlated to the theme and discusses and analyzes the contents of the verse. The verses in the Qur'an collecting by its relation to the topic of patience and in the end, we take the conclusion as the answer from the al-Qur'an.
\end{abstract}

Main Findings: Patience in the al-Misbāh Exegesis brings a personality model to the thought that the value of life hangs on patience as religiousness, ethics, and meaningful life. The personality model grows an involvement of psychological well being on the foundation of ideal humanitarian ethics in the Quran, which is the highest outcome of the patients.

Applications of this study: This study can be utilized by educators, in teaching and learning and psychologists.

Novelty/Originality of this study: The personality model of patience in the-Misbāh Exegesisis positive. This personality model will minimize a person falling in the concept of terrorism, and increases to realizing psychological well-being, especially related to meaningfulness in life and self-mastery.

Keywords: Psychology, Patience, Exegesis, Values, Humanitarian, Personality.

\section{INTRODUCTION}

Religion has the potential to increase psychological well-being and positive influence in human life by teaching the moral order to strengthen physical and psychological resources (Abdel-Khalek, 2014; Cohen \& Johnson, 2017). Religion gives human guidance for the purpose of life. The purpose of life refers to the values and meanings to maximize human potential according to nature (Sander, 2016). Life's goals are beneficial for human physical and mental health. Reduce the risk of depression, anxiety, stroke, cardiovascular disease, stress and, emotional properties (Culver \& Denton, 2017).

Therefore, seeing the function of the Qur'an as a guide for humans, the Qur'an teaches virtue to humans. The teaching of doing good in the Qur'an is referred to as al-birr, which is revealed by the Qur'an in Surah al-Baqarah (2: 177). Virtue is what brings closeness to God and is not just a face towards the east and west without meaning. The Qur'an firmly states that by doing good it will lead to the happiness of living in this world and the hereafter. The Qur'an mentions the form of virtue that is to believe in Allah, the Judgment Day, angels, books, prophets and give the treasure that he loves to relatives, orphans, poor people, travellers and to free the servants, perform prayers perfectly, perform zakat; those who keep their promises when they promise, those who are patient in narrowness, suffering and in war. So that virtue in the view of alQur'an is multi-dimensional, from the dimensions of science, faith, charity and closed with the ability to be patient at the end of surah al-Baqarah 177. In various religious literature, patience is valued as the highest level of religiosity and characterizes the nature of the faithful. Human patience includes two things, first, to reach the level of perfection. Second, humans can overcome problems patiently. Every person who has patience will easily achieve what he wants and who are impatient, it will be difficult to achieve what he wants. Patience is very much needed during difficult times, in an effort to reach the peak of spirituality and seek the pleasure of God (Pour \& Mongashti, 2014). The concept of patience in Islam, Christianity, Catholicism, Hinduism. and Buddhism occupies an important position (Subandi, 2015).

The important position of the concept of patience in Islam is because human behavior is motivated by the urge to desire toward the closeness and the pleasure of God. Psychological behavior is no longer dominated by impulses related to basic needs but motivated by spiritual impulse and mental clarity such as patience, honest, sincere, benevolent, and kindheartedness. So the ability to wait for greater results is called patience, self-control or delay gratification while the preference for smaller, faster ones is called impulsivity. Here, humans experience conflict between patience versus impulsiveness in many contexts, including in meeting the needs of life, looking for a partner, offspring, and working with others. In psychology, impulsivity is understood as a tendency to act recklessly, behavior that is characterized without thought, reflection or consideration of the consequences of earlier action. For this reason, patient education is very urgent. 
Therefore, the concept of patience in the Qur'an is the main concept because Allah attributes himself to the Most Patient (الصبور). Therefore the study of patience and its relations with personality and psychological well-being is important.

Personality is related to the morals and ethics of the Qur'an. Toshihiko Izutsu's view in his book Ethico-Religious Concepts in the Qur'an, states that the overall morals and ethics in the Qur'an are divided in two. First, the term in the Al-Qur'an which is related to the life of Muslims in their community (ummah)? Second, the term ethics is religious. The second concept is related to the essential nature of humans as religious beings. In Islam, the religious nature of humans is also ethical at the same time because there is no clear boundary line between the two. But the concept of ethics in the Qur'an is divided into three categories. First, the ethical attributes of God are reflected in His forgiving qualities. Actually, God does not have an ethical nature or attitude, because it is not responsible to anyone. But it is God himself who reveals himself by His attributes that are captured by humans and therefore are responded to apply to himself. That fact gave rise to a theory about the concept of divine ethics. Second, concerning the basic human attitude to God. This is the ethical responsibility of humans to the attributes of God. The response was manifested in an effort to grow the attributes of God so that humans have a moral character such as patience, compassion. Third, concerning the principles and rules of behavior that applies in social relations. That is what is referred to as social ethics (Rahardjo, 2002).

From the Qur'an's description of patience, it is clear that virtue and the highest position are obtained by one's patience. For example in surah As-Sajdah (32): 24, al-A'raf (7): 137 and al-Zumar (39): 10. In the versal-Baqarah's (2): 177,explained that the virtue of obedience that brings closeness to God is not the face of the east and the west without meaning, but the virtues that lead to the happiness of the world and the afterlife, that is to believe in Allah and the Last Day, the Angels, the Books, the Prophets and give the treasure they love to their relatives, orphans, the poor, the pilgrims and (liberating) freeing the slaves, performing perfect prayers, fulfill their promise when they promise, those who endure hardship, suffering and war. The perfect virtue is to believe in God and in the future until it absorbs into the soul and produces good deeds. This is where Allah praises the patient, who is true in faith and righteous.

The concept of patience needs to be re-examined because there an understanding that patience means to be resigned with destiny, or patiently means succumbing. Patience as an attempt to build character education to the good of life. Life is full of problems and conflicts. Therefore need to be patient in dealing with it. The Patience character becomes the primary basis in education as in the Prophet Moses story. While the story of Prophet Ismail demonstrates training patience needs to be early. Children are trained to resist desire not in a spoiled order to be patient in life. Because what is endeared is not necessarily good, likewise vice versa. So here in this paper researchers made an attempt to analyze Patience in the alMisbāh Exegesis work of M. Quraish Shihab from Indonesia, especially to describe and analyze the relationship of patience with the personality in tafsīr al-Misbāh.

\section{LITERATURE REVIEW}

Patient research in tafsīr al-Misbāh requires some relevant literature studies so that a theoretical picture can be obtained that can help understand the research problem. A literature review is used to understand the scope of research and to see differences with the results of research that has been done. And for this reason, the influence of religion in social life needs to be conveyed. Then, the meaningfulness of life is traced in the perspective of patients as a trait taught by religion to achieve human perfection. The influence of religion on social life cannot be separated from Max Weber's research on Protestant Morals. Although not specifically researching about patience, the literature helps the author to see the influence of religion in social life. Meanwhile, Victor Frankl spoke about the desire for a meaningful life (the will of the meaning). A meaningful life is the main motivation of humans. A meaningful life is the hope of conscience. Conscience is defined by Victor Frankl as subconscious spirituality. The conscience is the core of human existence and a source of personal integrity. Islam sees the heart as a stronghold to remain in virtue and holiness (Wahab, 2015).

The earliest writings on patients are al-Makkī, in his book QūtQulūb which had an influence on the thinking of later generations. Patience in QūtQulūb is referred to as the second ladder in the maqamat Sufism after the repentance. AlĢazalī is a writer who is inspired by the writings of al-Makkī in his book IhyāUlümuddin. Al-Ģazalī discusses patience regarding gratitude in his fourth book entitled "al-Munjiyat" (which saves). According to al-Ghazali, the character of a patient is related to two aspects, first, physical, which is to refrain from difficulties and fatigue in carrying out good deeds. This aspect of physical patience often brings pain and injury due to heavy burdens. Second, psychic, which is to refrain from the nature and demands of lust (Ghazalī, 1356). The generation after al-Ģazali is IbnQayyim al-Jawziyyah in his book IdātŞābirinwaSyākirīn. Patient character according to IbnQayyim is divided into two kinds. First, patiently refrain from anything unpleasant. The indicator does not complain when receiving disaster. Second, patience is followed by a brave attitude against and against something that befalls. The indicator, keeping the complaints that are suffered from real activities so that the impression of disaster is a challenge that is enjoyed with feelings of joy (Mujib, 2017).

Regarding psychological happiness, forbearance is regularly related to hedonic indicators. Besides adjusting personal, patience reduces depressed levels, achieving more contentment and pleasure, the satisfaction of achieving goals facilitates the relationship among patients and contentment, associate the assumption that patients rise hedonic through increased objective attainment, patience is also related to eudemonic well-being. The need for high autonomy and a lower level of loneliness, and the patient who scores more highly on other measures of virtue that are quantity of the eudemonic concept 
of "good life." Although this study is about the relationship between patience and psychological well-being but does not mention religious teachings as a basis for supporting psychological well-being (Schnitker, 2012).

Patience is defined as archetypal predisposition identical patience being but also understood as a condition. Forbearance is articulated as products that arise from the relations between persona and condition (Bülbül\& Arslan, 2017). The feelings from the past in wait, have a significant place in the valuation of effective patience. Muslims believe that illness, suffering, and death are part of life and can be a test from Allah to see the faith of his people. In a state of illness, Muslims must ask Allah for help with patience, and prayer, increase remembrance of Allah to get peace, beg for forgiveness, do more good deeds and read or listen to the verses of the Koran. Therefore, seeking help from Allah and praying during illness and hardship is recommended to Muslims (Ismail, Hatthakit, \& Chinawong, 2015). If the patient's life satisfaction increases, depression will decrease. Patience is connected to desire and pleasure. According to Aristotle, Hobbs, and Bentham, hedonism minimizes bad feelings and maximizes contentment, and well-being (Bülbül \& Izgar, 2017). Given patience as a new construct, research is needed on the construct of patience. Patience is a virtue or ideal value. Self-efficacy needs to be examined together with patience in other contexts where individuals may face difficult situations, such as family, government, work, organization, social groups in the wider community, and so on (Nugraheni, Rizka Fitri, Subhan El Hafiz, 2016).

Refining the excellence of happiness basically be influenced by existing innovative culture and education (Sergeeva $\mathrm{MG}$, Serebrennikova AV, Nikolaeva MV, Suslennikova EE, Bondarenko NG, 2019). Francis and Robbins showed a significant relationship between scores on the Oxford Happiness Inventory and scores on attitudes to Christianity. Several other researchers revealed that intrinsic and extrinsic religious orientation supports higher levels of well-being and happiness (Moltafet, Mazidi, \& Sadati, 2010). Khoynezhad's research suggests that religion has a positive relationship in solving the challenges of human life and minimizes the identity crisis (Khoynezhad, Rajaei, \& Sarvarazemy, 2012). Slamet Firdaus examines al-Muhsīn as an ideal human image, a human who reaches the peak of religious observance and practice. The results showed that al-muhsin is the ideal figure and has the highest dignity in the Qur'an (a'lāmarātib). One interesting interpretation related to Muhsin is the opinion of al-Dahhāk, who interprets the term muhsin in surah Yūsuf (12): 22 with "a patient figure" (Firdaus, 2011). Patience in the Indonesian thesaurus means 1. Feel at home, steadfast, resistant, careful. 2. emotionless, open heart, forgiving, tolerant. While the sense of patience is: resist feelings. The meaning of describing is cooling, soothing, calming, grant. While patience means: endurance and tolerance (Eko Endarmoko, 2009).The growth of morals in Islam is largely a method for controlling emotions. Emotional control supports to construct and maintenance moral feelings such as compassion, honey, kindness, and bravery and to combat and destroy destructive feelings such as distrust, annoyance, egoism, and fearfulness. Therefore, constructing a character has a lot to do with patience and perseverance in controlling negative emotions and strengthening positive emotions. Emotion management that leads to moral values will also lead someone to get a spiritual, and good lifetime (Fatimah Abdullah, 2012). The hurry of any kind is reflected not only in a breach of the importance of patience but also in the effect of the evil spirit encouragement. The result of impatience is failing, or as the Egyptians said, "a man in a hurry could not lead a camel." The idea of the time span is represented by the concept of a lengthy breath. Self (Nafs), Soul (rūh), and breath symbolically in the situation of exercising patience. Ego or soul must be directed and well-ordered, although his soul (rūh) is given time to return and manage with situations that unpleasant or in bad conditions (el-Aswad, 2014). According to Skinner, the disease arises when self-dynamics goes in the wrong direction, e.g. intellect intuitive wisdom. Self-balancing is potentially damaging, alienating people from wellbeing. Therefore necessary balance. Balance occurs when the integration of faith with moral values and the ability to live by virtuous and patient (Joshanloo, 2013).

In summary, several studies consistently show a negative relationship between intrinsic orientation towards religion, depressive symptoms and anxiety and a positive relationship between extrinsic orientation toward religion and symptoms of depression and anxiety. Thus patience supports human mental health, reduces depression and anxiety (Curry, Price, \& Price, 2008). While in psychology, patience is a construction that is not learned directly. In the psychological literature, patience is just the opposite of impatience. The assumption is patience exists because of impatience. However, other research proposes a multi-dimensional patience model based on qualitative studies. Following the multi-dimensional model, patience is on a continuum with different potential in various situations (Dudley, 2003). Patience is the key to goodness in the Qur'an and refraining from lust is a great way to instill virtue in human character. Likewise, al-șabr (patience) is explained by the Qur'an as one of the greatest virtues (Oliver Leaman, 2006). Therefore, the faith has a significant influence on the tranquility of the human psyche, the faith makes people more confident, patiently facing the burden of life, calm and peaceful, happy, as depicted in the al-Qur'an (Q.S. 6: 82, 13: 28, 64: 11)(Najatî, 2008).

\section{METHODOLOGY}

The research uses a qualitative approach, starting from data collection, display, data reduction and conclusions. While the data analysis techniques in research, use the content analysis model (content analysis). In addition, research-related data are examined from relevant research sources and results. After being collected, the data are classified and analyzed and described in accordance with the sub discussion. Furthermore, the data obtained were analyzed using coding techniques consisting of three stages, namely: first, open coding, identifying categories of themes that emerge, second, axial coding, researchers trying to see the relationships between categories one with another, and third, selective coding, systematically selects the most basic categories, links them to other categories and validates the relationship (Anselm Strauss, 2009). 
Data is processed by: first, observing aspects of completeness, validity, and relevance to the theme of the discussion. Second, the classification and systematic data, are formulated in accordance with the main problem. Third, carry out further analysis of data that has been classified and systematized by using theorems, rules, theories, and concepts accordingly. Fourth, interpretation, which is to explore and grasp the meaning and nuance or expression so that a correct understanding is achieved.

\section{DISCUSSION / ANALYSIS}

In positive psychology, patience has not yet been developed as a strength of character such as gratitude. But lately, the passion to see the concept of religion and psychology is very great to see the character of patience. Patience in positive psychology is interpreted as a tendency to wait calmly, without frustration in the face of difficulties or suffering. Patience applies every circumstance and time. In everyday life, patience is needed when traffic conditions for example. In the long run, patience is needed when parenting or when contracting a disease. Even though it frequently contains a sequential factor, patience is needed in conditions when dealing with hard people. Patience is usually understood as disposition, for example, he is somebody who has patience. Patience is seen as a state she waits patiently. Second, the conceptualization of patience is interrelated, so it is essential to reflect both of them as important landscapes. Sincere patience hangs on behavior and emotions.

In Positive Psychology, patience is related to the value of virtue, self-regulation, a choice between time as in the economic world and emotional regulation. Peterson and Seligman, pioneers of empirical studies of the strength of character and virtue, see the concept of patience not as a separate virtue but a mixture of qualities such as perseverance, openmindedness, and self-regulation. Patience attracts attention to empirical research as a unique psychological construct. Talking about self-regulation is often mistaken as patience. Although self-regulation skills can function to calm emotions, Schnitker and Emmons state that self-regulation, although often involving strong emotions, is characterized by behavioral responses, whereas patients are characterized by emotional responses. Patience is different from self-regulation because patience is related to emotions.

Therefore it is necessary to examine the concept of patience in the Tafsīr al-Misbāh.On the other hand, the Tafsir is named Tafsīr al-Misbāh, because al-Misbāh is found in the Qur'an of Surah al-Nūr verse 35. Al-Misbāh means light. The QuraishShihab places the guidance of Allah like a lamp (al-Misbāhn) in the glass and illuminates the hearts of believers. While the title is given the word "message" it means the Qur'an is a message (revelation) from God as a guide to mankind. While the word "impression" is intended, tafsīr al-Misbāh is a compilation of the opinion of interpreters, both classical and contemporary. Furthermore, the word "compatibility" in the sense of verse and surah in the Qur'an is always relevant. According to the Quraish Shihab, the text of the Tafsīr al-Misbāh is in response to criticism stating that there are systematic errors in the Qur'an's writing. Whereas in the system of the Qur'anic writing there are special privileges known to science. In addition, the QuraishShihab hoped that the presence of tafsīr al-Misbāh could explain the meaning of the Qur'an and be able to convey its messages. On the other hand, the QuraishShihab hopes that tafsīr al-Misbāh does not disappoint those who are interested in learning it.

As mentioned earlier, the word patience follows its derivation in the Qur'an 103 times. According to the Quraish Shihab, in the Qur'an, it is repeated a hundred times. All words that use a series of letters şabara $(\omega)$ (ص) in the context of human description, among others, the command of patience, praise of patience, patience, the nature of patience and its impact, the criticism of those who fail. According to Imam Ģazāli, more than seventy times Allah SWT outlined the problem of patients in the Qur'an. According to the Quraish Shihab, the word patience spread in 103 verses and in 45 surahs. A total of 29 surahs belong to the Makkiyyah group and 17 surahs belong to the Madaniyyah group. The word patience includes 90 verses. Quraish Shihab concluded that patients require fortitude to face something difficult, severe, bitter, which must be accepted and faced with full responsibility. On the basis of the meaning that the writer concludes, religionists formulate "patience as a restraint or limit the soul from its desires in order to achieve something good or better" (Shihab, 2012b).

God gives the potential for self-defense in living things, one of which is patience. Because life requires patience, the gift of patience aims to maintain emotional stability so that life remains stable and is able to overcome the problems of life by looking for better opportunities. Patience is like a fortress when facing a strong enemy. Patience is different from surrender and incompetence. People who surrender and feel unable to show impatience to change the existing conditions, namely impatience to try or impatience to struggle.

One of the good qualities is facing evil with kindness, which is only bestowed upon people who are accustomed to patience and perseverance and patience. That quality is not bestowed except for the fortunate and noble souls. The above verse explains how much influence a good deed has on a fellow human being even against an opponent. Because humans have feelings. Feelings are a collection of emotions. Emotion is a psychiatric situation that encourages to do something but is temporary, while a feeling is related to an object experienced based on knowledge and experience. The feeling is a collection of many emotions that occur regularly and focused on an object. Student hatred of the teacher, for example, occurs when emotions are afraid because the teacher is being rude to students. These emotions merge into one so that the teacher's expectation is absent or has a disaster making the student happy for example. Besides that, the human soul is very magical. In dealing with something, humans are sometimes contradictory. Therefore there is no love without hate, no mercy without cruelty. Because it is necessary to forgive others because the Messenger of Allah is famous as forgiving. 
In the Qur'an, patient orders are found in various contexts, including:

1. Waiting for the Ruling of God, in Surah Yusuf (10): 109.

2. Until the coming of God's promise or the day of victory, surah ar-Rūm (30): 60 .

3. Facing the ridicule and harassment of unbelievers, surah Taha (20): 130.

4. Encouraging the impulse to commit improper retribution, an-Nahl (16): 127.

5. Performing Worship, surah Maryam (19): 65.

6. Facing catastrophe, surah Luqman (31): 17.

7. Obtain whatever you want, surah al-Baqarah (2): 153 (Shihab, 2012a).

The Qur'an invites people to be patient. Benefits of patience for humans according to Najati are:

1. Educate yourself

2. Form the main personality

3. Increase the ability to bear the trials of life.

4. Renew strength to face the problems and trials of life.

5. Encouraging the continuity of jihad in upholding the religion of God (Najatī, 2008).

Patients who are not afraid to accept something that hurts, do not feel weak and commit suicide when experiencing suffering and trials in life. All trials become learning because they understand that all trials come from God, to find out who can be patient. Patiently teach someone to work, focus on achieving goals both in the field of science and the field of work. Because human goals, both in the social, economic and political fields, require time and energy to achieve them. Getting used to learning patiently, expending energy and working is an important trait in achieving success and achieving goals. If someone has learned to be patient in bearing the burden of life, trials, suffering and hostility, patients in worshiping God and being obedient to Him, fighting lust, patience in creation and production then he will become a human who has a mature, balanced, perfect personality, productive, real and lost anxiety change security from anxiety and anxiety of life.

Patience is a personality trait among other personality traits. Patience is significantly correlated with religious, spiritual, openness, extraversion, future behavior, time orientation, hedonist, past, self-control, and attention. Patience is negatively correlated with neurosis, negative affection, and openness. Extraversion is a predictor of patience. Meanwhile, some literature that examines mental health shows a relationship with patience. Patience and well-being are positively correlated when facing difficulties. The noncognitive skills in education economics and social are self-control and to be patience. Educational interventions to make children see the future by identifying problems of self-control and exploring the role of commitment (Fitriah M. Suud, Abd. Madjid, 2019). In addition, there is an important correlation between forbearance, obligation, and interval inconsistencies as well as learner traits and successes such as in school. Castillo showed a correlation of patience with school achievement and found many students who patiently succeeded in their school.

Given the very strong relationship between choices in childhood and their consequences throughout life, the problem of forming major traits in childhood is the attention of scholars and policymakers. The idea that traits can be formed is very essential for planning instructive policies, besides the family, the school can arrange for amilieu where these abilities can be educated and established. In the situation, the training of self-control and patience can aim to (1) focus on the aids of forward-thinking behavior, (2) increase attentiveness unfairness in policymaking between times and contemporary strategies such as an obligation to overcome the problems of self-control. Early medications maybe have a direct influence on education attainment over schools to change behavior and achieve success, and in a long time are socially and economically beneficial.

Personality is a person's response to others. On the other hand, personality is interpreted by ability and social intelligence as well as strong prominent characteristics, which are created by others against others. From the language side of personality comes from the Latin "persona" means mask. Personality means a mask to hide one's identity (Lynn Wilcox, 2013). What is the role of patients with personality? Personality is defined as an eternal pattern in understanding relationships and ways of thinking about the environment and oneself. Humans react and deal with the world and the people around them in a consistent and unique way. Humans have different physical structures, so each human is unique and has a distinctive personality. A personality trait is a prominent aspect of personality that arises in various social contexts. The characteristics of each person are different in interacting with the world. These characteristics form the personality. Research in psychology confirms what Allah revealed to us in the Qur'an. There is evidence to show that humans are born with different unique temperaments, which affect many aspects of the developing personality (A. Utz, 2012). In literature, the relationship between patients and well-being is very close because individuals who are patient, are less depressed (Schnitker, 2012). The relationship between patients and well-being is positive. Therefore, patience is 
closely linked to hedonic and eudaemonic well-being, increasing happiness and reducing negative feelings. In addition, patience is related to positive social characteristics and virtues.A person who has patients show a more empathic and thankful. The role of patience is defending the hedonic of emotional attitudes in circumstances that make stress, supports overcome frustration in a harmonious way, facilitates positive interpersonal interactions. It can be said that patients affect the well-being of the hedonist indirectly and hence given growth lifespan satisfaction and optimistic moods and creates it stress-free to achieve targets. The relation between patience, positivity, hopefulness is positive (Bülbül \& Izgar, 2017).

In daily practice, Muslims try to change the virtues of patience into behavior patterns or personality traits that show how to overcome difficulties and suffering. A popular saying like patience is the virtue of showing nature (el-Aswad, 2014).M. QuraishShihabin his book Ensiklopediaal-Quran: KajianKosakata, words of patience in various forms, whether verb or object mentioned 103 times, in 46 surahs, 29 surahs including Makiyah and 17 other Maddaniyahsurahs and in 101 verses (Shihab, 2000). Humans find their personality intact and integral if they focus their transcendental orientation on God, the Almighty God. Conversely, for humans, placing themselves and dignity under each other or under the objects and natural phenomena make personality incomplete. Humans lose their freedom and the loss of freedom results in lost opportunities and the possibility of developing themselves to the highest level.

At least some personality models will be born related to patience:

1. Muhsinin's personality is a person who likes to do good

2. The personality of the muttaqin is that which protects itself from all kinds of transgressions and avoids all that may cause the wrath of God.

3. The personality of al-mukhbitīnis that when called the name of Allah shakes his heart because he realizes greatness, beauty.

4. The personality of $i b \bar{a} d$ al-rahmmān which depicts tranquility and humility is accompanied by the power of tears.

5. Ribbiyun personality.

As with every Divine word, the holy verse is laden with meaning, so that through the act of interpretation, it can also be a source of study and life value. But the message to convey is clear that while striving to achieve higher and eternal goals in life, we cannot forget the present. And the combination of the two is later associated with ihsân, clearly indicative of a life of devotion for good and not to do harm (Madjid, 1999). There are two verses that speak Muhsinin. First, Surah Hūd (11): 115 and second, Surah al-Nahl (16): 126. The commands and prohibitions in the previous verse are indeed not easy, and God gives provisions to carry them so that the task can be carried out properly. According to al-Biqā'i, because humanity is a container of weakness and carelessness, Surah Hūd (11): 115 gives instructions on the best way to cover up small sins caused by human weaknesses and to avoid the adverse effects of negligence and lethargy to achieve the ordered istiqāmah by the previous verse. This verse teaches patience and prayers regularly and correctly in accordance with the provisions, both in harmony, terms, and sunnah-sunnah. Besides Salat, they must be patient in facing difficulties in carrying out Allah's commands. Because without patience it is difficult to carry out obedience let alone istiqāmah and it is also difficult to achieve success in world life let alone an afterlife. Therefore this verse concludes with the statement that Allah did not waste the rewards of al-muhsinīn, those who do good (Shihab, 2012c). In the surah Hud (11): 115, Allah said; And be patient, for indeed, Allah does not allow to be lost the reward of those who do good.

That Allah requires ihsân for everything, is also confirmed in the Scriptures that Allah made good, the best (ahsana, carrying out ihsân), everything that He created. Then, besides ihsân, another expression is also used, namely itqân which means more or less is to make or do something seriously and thoroughly so that it is neat, beautiful, orderly and in accordance with one another from its parts. So it is said that all of this nature is a carefully created art of God. In popular language, God's words show that God has never been half-hearted, mediocre, half-hearted in creating everything (Madjid, 1999). Don't expect humans to give birth to patience. Allah, will give birth to human beings through good whispers that help to be patient, make it easy and willing to accept what is encountered. Thus patience becomes a beautiful patient without complaining and without defiance. The editorial of the verse suggests there was no retaliation and continued orders of patience, leading the Prophet Muhammad to imitate his people. Thus he became a Muhsin and his people became muhsinin. Because the Prophet Muhammad became the leader of the Muhsinin and Allah with him. Thus the Prophet Muhammad will win (Shihab, 2012d).

Explanation in the surah Hūd (11): 49, about the muttaqīn who keep themselves from all kinds of violations and avoid all that can cause the wrath of God, because sanctions violate the afterlife (Shihab, 2012c).

Al-Mukhbitûncomes from the word al-khabtu or al-ikhbât. al-Khabtu in the sense of language, means a wide and quiet surface, a kind of deep, wide, lonely, and overcast valley(Ibn Manzūr, 1300). On this basis, IbnAbbâs interprets the wordal-mukhbitin in this verse as mutawâdhi în (humble ones). Likewise ad-Dhahâq and Qatâdah. While according to Mujâhid, mukhbitîn means Muthmainnin, a person whose heart is at peace with Allâh. Ats-Tsauri thinks mukhbitîn means a quiet, prosperous person, an open heart with destiny (qadha andqadar)Allâh and always surrender to him. According to alAkhfâsi, mukhbitin means those who are calm (khusyu). While according to Ibrahim an-Nakhâ'i, it means those who pray 
and are sincere. According to al-Kalby, it means gentle-hearted people (Shihab, 2012c). The previous verse talks about the command to surrender to Allah and who carried it out is called al-mukhbitīn with characteristics as in surah al-Hajj (22): 35. When called the name of Allah, al-mukhbitin trembles his heart because he realizes the majesty, beauty, and power of Allah and patience with what happens, is very resilience in facing various difficulties or disturbances. In addition, carrying out șalāt and spending his fortune.The word patron aṣ-ṣabirīn (الصابرين) provides stability for the person with it. The inclusion of this attribute in the context of the pilgrimage suggests how important this aṣ-irabirīn is. In particular, in the Hajj where the weather, place, and visitors are so difficult compared to other places and times (Shihab, 2012e).Prayers that form a very high religious. Furthermore, religiosity can have far-reaching implications in this life, both outward and inward life. Due to the calmness of the soul due to communication with God, the person who performs the prayer obediently will have a more balanced soul, full of hope but does not lose self-awareness or arrogance, because they do not complain if overwritten by misfortune and do not become stingy when experiencing luck. Successful prayer will have the effect of forming an attitude of the soul that is free from worry out of place in the face of life. Not only because of faith, is always associated with hope (as kufr is associated with despair), but also because someone who truly grows in himself is steadfast in life orientation in order to attain the pleasure of Allah alone (Madjid, 1999).

The word servant in the Qur'an and all the words in it are mentioned 275 times. The word al-Rahman is known to one of his husbands. This word is often associated with al-Rahman. In the Qur'an, the word al-Rahman is repeated 57 times. Thus, the Servants of God (ibad al-Rahman) is a figure of a servant who always worships God who has the perfection of himself as a noble servant. First, walk in the true meaning. The second meaning is to walk in the meaning of parable(majazi). The word walk is the expression of all human interaction in his life, not just walking. The infidels spoke the words of calmly, with authority, humility, gentleness, and obedience. These meanings correspond to the two meanings above. That is, walk calmly, with authority, pity, and love (Baqi, 1364).

The qualities that ibādar-rahmān wore in the previous verse depict the serenity and humility of the face of fear. Opportunity and optimism coupled with concern and fear of al-Khāliq, sincerity, openness, simplicity, and moderation as well as the willingness to accept advice and criticism besides the love of family, environment, and community, are clear personal decorations. To the extent of patience and perseverance in surah al-Furqān (25): 75 this means the ability to carry out religious guidance with the help of Allah. The word prayer (تحية) here means prayer for life. This word describes the life and the endless source of life from God. While the word salām (سلام) is the basic meaning of escape, defect, and disgrace. The word is spoken when something unwanted happens but does not happen(Shihab, 2012f). It is mentioned in the verse above that the servants of the Most Merciful God ('ibâd al-rahmân) when walking on earth, walk in humility. And if people talk to you like fools, answer or say goodbye. Worships God and realizes that he is always threatened by misery, so sincerely begs God to be avoided. It's about wealth, not wasteful, stubborn, but halfway between the two. Sincerely worshiping God alone (not shirk, which can break the purpose of living right), and respecting the lives of others who are protected by God, and always maintaining their dignity. Do not make false testimonies, and if they encounter useless things, avoid them with pride. Then, when reminded of the teachings of God, do not be ignorant, seem deaf or blind. Has high family responsibilities (loving his life partner, husband or wife, and offspring). Have a sense of social responsibility, with a strong desire, expressed in prayer to God, to do something of a leadership nature, the attitude of living by paying attention to the people. Not arrogant even when dealing with fools, not losing patience, but instead hoping for good or peace or solemnity for him. His high sense of humanity also made him serious about his desire to learn and find the truth. Showing genuine concern for the happiness of his family and his community (Budi Munawar Rahman, 2006).

The word ribbiyyūn (ربيون) is a plural of the word rabbi ربي) equivalent to the word rabbun (رب) rab. It means to follow God's law. According to ash-Shafi'i, not weak, lethargic and surrender are three stratified things. Weak has to do with the physical that can deliver lethargy and sagging determination, the second ushered in surrender (Shihab, 2012c). Muhammad SayyidṬantawi uses the word wahn (وهن) in the sense of weakening the determination of the heart to shake, while the third is the weakness produced by wahn. The Qur'an uses the words wahn and daif (ضعف) for physical weakness and second for mental weakness (Shihab, 2012c).

Patience is a strength and personality trait that is needed for the growth and happiness of humankind. Harned stressed the significance of patience for a lifespan (Bülbül \& Izgar, 2017). Patient relations with personality are related to people's ability to respond to stimuli that are internal and external, the results of which are able to foster prosperity. The faith in Muslims is that God is who gives life and death. Muslims frequently do not reflect sorrow and illness as a penalty. As an alternative, get the pardon and divine merit if patience is sustained for the duration of facing troubles. Muslims have faith in God and look for aid from God by worship and charitable to those who need without distinction of race, belief or nation (Hassan, 2013). The relationship between patience and well-being in some literature is very significant. Schnitker and Emmons said that patients qualified less unhappiness. Patience is an arrangement of harmful stimulation effects, such as tired coming up for people, and limitations in some situations. Despite the differences in conceptualization, definitions of patience complement everyone. To response time and conditions need patience. For illustration, patience in dealing with discomfort due to long-standing or in traffic jams. In addition, the properties of patience are cognitive and effective. These indications that patience is not an innate condition but a situation obtained. Patience is a response suspension, which reproduces passions such as calm, kindness, and responsiveness (Bülbül \& Arslan, 2017). Ryan and Deci believe that patience is associated with hedonic and eudaemonic well-being, and increases happiness to the maximum and reduces bad 
moods. A person whose patience shows a more empathic and grateful. Patience also includes strong virtues such as equality and justice. Diener expressed patience protecting the health of hedonists, especially feelings stress conditions, help the people to deal without frustration in extra pleasant ways, facilitating optimistic personal relations.

Therefore, it can be said that patience affects the welfare of the hedonist indirectly and growths lifetime happiness, constructive moods and creates it relaxed to realize objectives. The people who are patient have little bad influence, low sadness, few healthiness problems, and enlarged lifetime contentment. Experimentally found an optimistic relation between patience, positivity, and hopefulness. According to Schnitker, patience is relatively fatalistic. If happiness increases, unhappiness will decrease. Patience is related to pleasure and happiness. Minimizing negative emotions and maximizing happiness and comfort are the goals of hedonism according to Aristotle, Hobbs, and Bentham (Bülbül \& Izgar, 2017). Patience relations with personality are related to people's ability to respond to stimuli that are internal and external, the results of which are able to foster prosperity. (Hassan, 2013).

Evaluation separately or not, the relationship between patience and self-determination is very significant. Schnitker states that the characteristic patience in the form of behavior and affection. Patience in waiting is behavioral and calm is affection. Patience in dealing with discomfort due to long-standing or in traffic jams. On the other hand, patience has cognitive and affection that suggests that patience is not a congenital condition but a condition is acquired. Patience appears in controlling emotions in the form of a calm attitude, full of sympathy, and also empathy.

Self-control is a set of sublime character traits that are an important aspect of emotion and spiritual intelligence. Personal power produces a clear principle of life to face highly challenging environmental conditions. Individuals who have personal powers can choose the most appropriate response to the principles of life. Self-control is the most important thing for human existence. This is just one important aspect of patience.Self-control or patience is a very comprehensive and broad concept. Individuals do patience in many ways because they patiently have tremendous benefits. Patience achieving a superior morality and creating an attractive and peaceable life. In addition, will earn a double reward in the hereafter in exchange for patience in the world. Some good and wonderful effects of the concept of patience experienced in this world and will be manifested in the next life.

One achievement of the nature of patience is intelligence. Intelligence because patience helps people to avoid fear, anxiety or emotional impulsivity. The patient's condition allows humans to see an event in a calm, independent way and thus can reach intelligent conclusions and favorable decisions. This intelligence needs to be developed in Islamic education by instilling a spirit of patience in facing life's challenges. Patiently will develop an effective, responsible, disciplined, innovative and patient personality. If education ignores this intelligence, then the resulting education output will fail to face life's challenges.

\section{CONCLUSION}

Quraish Shihab concluded that patience requires fortitude to face something difficult, severe, bitter, which must be accepted and faced with full responsibility. On the basis of the meaning that the writer concludes, religionists formulate "patience as restraint or limit the soul from its desires in order to achieve something good or better". On the other hand, the psychological values of patience in Tafsīr al-Miṣbāh have relevance in the development of personality. The term personality related to patience is first, Muhsinin's personality, namely the attitude of living life with sincerity for the good of all, and do not let our actions cause damage. Second, the personality of the mukhbitīn, when called the name of Allah, trembles his heart, is patient with what has happened, is very tough in facing various difficulties or distractions, and carries out āalāt and exerts his fortune. Third, Muttaqīn's personality, which is to guard against all kinds of violations and to avoid everything that can cause the wrath of Allah Almighty. Fourth, the personality of Ibad al-Rahmān, that is a calm and humble personality accompanied by authority from the face. Grace and optimism are accompanied by concern and fear of al-Khaliq, sincerity, openness, simplicity, and moderation as well as the willingness to accept suggestions and criticism in addition to love from family, environment, and society. And fifth, the personality of the ribbiyyun or the personality of the Rabbani that follows the Shari'a of God, is not weak, lethargic and surrender. Maybe this is the model of big five personalities according to patience character. From the five personality models that relate to the term patience in Tāfsīr alMisbāh is positive. For example, the Muhsinin term emphasizes goodness. Hopefully, with this personality model, will minimize a person falling in the concept of terrorism. Because heaven turns out to be patiently accomplished both socially, economically and politically without having to take up weapons at war in the Middle East, or jihad with suicide bombs like some extreme movements.

\section{LIMITATION AND STUDY FORWARD}

This research is limited to al-Misbāh Exegesis. Further research needs to look at patient indicators in the field especially in Islamic psychology.

\section{PRACTICAL IMPLICATION OF THE STUDY}

The effects of this study point out that the psychology of patience is a solution to mental health and emotional stability and self-control. So, patience is the main value as a working foundation for education practitioners, counsellors, and psychologists, especially in teaching and learning and survival. 


\section{ACKNOWLEDGMENT}

The authors thank Abd. Madjid and Mega Hidayati for their supportive comments and supervision on the manuscript.

\section{REFERENCES}

1. A. Utz. (2012). Psychology from the Islamic Perspective. In Intellectual Discourse (Vol. 20). Malaysia: International Islamic Publishing House. 97.

2. Abdel-Khalek, A. M. (2014). Religiosity and Well-Being in a Muslim Context. https://doi.org/10.1007/978-94017-8950-9_4https://doi.org/10.1007/978-94-017-8950-9_4

3. Anselm Strauss, J. C. (2009). Dasar-Dasar Penelitian Kualitatif. Yogyakarta: Pustaka Pelajar. 51

4. Baqi, M. F. A. (1364). Al Mu’jam Al Mufahros Li Alfadhil Qur'anil Karim. Kairo Mesir: Dārut Hadiş. 400.

5. Budi Munawar Rahman. (2006). Ensiklopedi Nurcholish Madjid: Pemikiran Islam di Kanvas Peradaban, Edisi Digital 2 (1st ed.). Jakarta: Paramadina. cxxxvii.

6. Bülbül, A. E., \& Arslan, C. (2017). Investigation of Patience Tendency Levels in Terms of Self-determination, Self-compassion and Personality Features. Universal Journal of Educational Research, 5(9), 1632-1645. https://doi.org/10.13189/ujer.2017.050921

7. Bülbül, A. E., \& Izgar, G. (2017). Effects of the Patience Training Program on Patience and Well-Being Levels of University Students. Journal of Education and Training Studies, 6(1), 159. https://doi.org/10.11114/jets.v6i1.2900

8. Cohen, A. B., \& Johnson, K. A. (2017). The Relation between Religion and Well-Being. Applied Research in Quality of Life, 12(3), 533-547. https://doi.org/10.1007/s11482-016-9475-6

9. Culver, J., \& Denton, M. L. (2017). Religious attachment and the sense of life purpose among emerging adults. Religions, 8(12), 274. https://doi.org/10.3390/rel8120274

10. Curry, O. S., Price, M. E., \& Price, J. G. (2008). Patience is a virtue: Cooperative people have lower discount rates. Personality and Individual Differences, 44(3), 780-785. https://doi.org/10.1016/j.paid.2007.09.023

11. Dudley, K. C. (2003). Empirical Development of a Scale of Patience (West Virginia University). Retrieved from https://researchrepository.wvu.edu/etd/1920

12. Eko Endarmoko. (2009). Tesaurus Bahasa Indonesia. Jakarta: Gramedia Pustaka Utama. 677.

13. el-Aswad, E.-S. (2014). Patience in Sunni Muslim Worldviews. Encyclopedia of Psychology and Religion, 13181321. https://doi.org/10.1007/978-1-4614-6086-2_9317

14. Fatimah Abdullah. (2012). Teaching Islamic Ethics and Ethical Training: Benefiting From Emotional and Spiritual Intelligence. International Journal of Humanities and Social Science, 2(3), 224-232.

15. Firdaus, S. (2011). Konsep Manusia Ideal Dalam Al-Qur'an (Studi Profil Muhsin Dalam Perspektif Ayat-Ayat Ihsan). 23.

16. Fitriah M. Suud, Abd. Madjid, S. (2019). The Study of Educational Honesty Stages Implementation in an Indonesian School. Humanities \& Social Sciences Reviews, $7(4), \quad 502-510$. https://doi.org/10.18510/hssr.2019.7467

17. Ghazalī, A. H. al. (1356). Ihyā Ulūmuddin (Juz 7). Lajnah Nasr Śaqafah Islāmiyyah.

18. Hassan, M. (2013). A Guide for Caring Muslim Patient. Turku University.

19. Ibn Manzūur, M. ibn M. (1300). Lisān Al- 'Arab (p. 15 v). p. 15 v. Beirut: Dāru Sadir.

20. Ismail, S., Hatthakit, U., \& Chinawong, T. (2015). Caring Science within Islamic Contexts: A Literature Review. Nurse Media Journal of Nursing, 5(1), 34. https://doi.org/10.14710/nmjn.v5i1.10189

21. Joshanloo, M. (2013). A Comparison of Western and Islamic Conceptions of Happiness. Journal of Happiness Studies, 14(6), 1857-1874. https://doi.org/10.1007/s10902-012-9406-7

22. Khoynezhad, G., Rajaei, A. R., \& Sarvarazemy, A. (2012). Basic religious beliefs and personality traits. Iranian Journal of Psychiatry, 7(2), 82-86.

23. Lynn Wilcox. (2013). Criticism of Islam Psychology. Yogyakarta: IRCiSoD.

24. Madjid, N. (1999). Islam: Doktrin dan Peradaban (Cet. IV). Jakarta: Penerbit Paramadina. 416.

25. Moltafet, G., Mazidi, M., \& Sadati, S. (2010). Personality Traits, Religious Orientation and Happiness. Procedia Social and Behavioral Sciences, 9, 63-69. https://doi.org/10.1016/j.sbspro.2010.12.116

26. Mujib, A. (2017). Teori Kepribadian Perspektif Psikologi Islam (Cet. 2, Vol. 2). Jakarta: Rajawali Press. 51.

27. Najatī, M. U. (2008). Psikologi Qur 'ānī. Surakarta: Aulia Press Solo. 40.

28. Nugraheni, Rizka Fitri, Subhan El Hafiz, F. R. (2016). Hubungan antara Kesabaran dan Academic Self Efficacy pada Mahasiswa. Jurnal Ilmiah Penelitian Psikologi: Kajian Empiris \& Non-Empiris (JIPP), Vol. 2(2), $15-23$.

29. Oliver Leaman. (2006). The Qur'ān : an Encyclopedia (Cet. 1). New York: Taylor and Francis.

30. Pour, A. R. M., \& Mongashti, N. (2014). Education of Patience in the social relations in the Quran. Vol. 30(1), 335-338. Retrieved from http://waliaj.com/wp-content/2014/Special Issue 1, 2014/58 2014-30-S1-pp.335-338.pdf

31. Rahardjo, M. D. (2002). Ensiklopedi Al-Qur'ān: Tafsir Sosial Berdasarkan Konsep Konsep Kunci. Jakarta: Paramadina. 418.

32. Sander, R. (2012). Religion and wellbeing. In Nursing Older People (Vol. 24, pp. 13-13). https://doi.org/10.7748/nop.24.4.13.s11

33. Schnitker, S. A. (2012). An examination of patience and well-being. Journal of Positive Psychology, 7(4), 263280. https://doi.org/10.1080/17439760.2012.697185 
34. Sergeeva MG, Serebrennikova AV, Nikolaeva MV, Suslennikova EE, Bondarenko NG, S. A. (2019). DEVELOPMENT OF UNIVE RSITY TEACHER' S INNO VATIVE CULTURE. Humanities \& Social Sciences Reviews, 7(4), 20-25. https://doi.org/10.18510/hssr.2019.743

35. Shihab, M. Q. (2000). Ensiklopedi al-Quran: Kajian Kosakata (Cet. 1, Vol. 3). Jakarta: Lentera Hati. 891.

36. Shihab, M. Q. (2012a). Tafsīr al-Misbāh, Pesan, Kesan, dan Keserasian al-Qur'an (Vol. 1). Jakarta: Lentera Hati. 460.

37. Shihab, M. Q. (2012b). Tafsīr al-Misbāh, Pesan, Kesan, dan Keserasian al-Qur'an (Vol. 14). Jakarta: Lentera Hati. 458..

38. Shihab, M. Q. (2012c). Tafsīr al-Misbāhn, Pesan, Kesan, dan Keserasian al-Qur'an (Vol. 5). Jakarta: Lentera Hati. 773.

39. Shihab, M. Q. (2012d). Tafsīr al-Misbāh , Pesan, Kesan, dan Keserasian al-Qur'an (Vol. 6). Jakarta: Lentera Hati. 780 .

40. Shihab, M. Q. (2012e). Tafsīr al-Misbāhn, Pesan, Kesan, dan Keserasian al-Qur'an (Vol. 8). Jakarta: Lentera Hati. 207.

41. Shihab, M. Q. (2012f). Tafsīr al-Misbāh, Pesan, Kesan, dan Keserasian al-Qur'an (Vol. 13). Jakarta: Lentera Hati. 167.

42. Subandi. (2015). Sabar: Sebuah Konsep Psikologi. Jurnal Psikologi, 38(2), $215-227$. https://doi.org/10.22146/jpsi.7654

43. Wahab, A. J. (Ed. . (2015). Indeks Kesalehan Sosial Masyarakat Indonesia. Jakarta: Kementerian Agama RI. 18. 